\title{
Cross-Physical Dependence of Several Drugs in Methaqualone-Dependent Rats
}

\author{
Tsutomu SUZUKI, Yoko KOIKE, Yasuhiro CHIDA* and Miwa MISAWA \\ Department of Applied Pharmacology, School of Pharmacy, Hoshi University. \\ 2-4-41 Ebara. Shinagawa-ku. Tokyo 142. Japan \\ ${ }^{*}$ Gerontology Research Center. National Institute on Aging. National Institutes of Health. \\ 4940 Eastern Avenue, Baltimore. Maryland 21224, U.S.A.
}

Accepted January 8. 1988

\begin{abstract}
We investigated the characteristics of physical dependence on methaqualone. Rats were made physically dependent on methaqualone by the use of the drug-admixed food (DAF) method for 33 days. Pentobarbital, barbital, ethanol and diazepam were cross-administered against methaqualone to evaluate the degree of suppression of methaqualone withdrawal signs as an index for the cross-physical dependence liability of these drugs to methaqualone. To evaluate the cross-physical dependence liability, we used AUC of body weight loss and withdrawal scores between the first cross-administration ( $9 \mathrm{hr}$ after the withdrawal) and $27 \mathrm{hr}$ after the withdrawal. AUC of weight loss was significantly suppressed by the four test drugs as compared to each control. Withdrawal scores were also significantly inhibited by the cross-administration of barbital, ethanol and diazepam. Considering that the rats given barbital or ethanol fell asleep after the cross-administration, diazepam seems to cause the strongest suppression of methaqualone withdrawal signs among the four test drugs. Thus, physical dependence on methaqualone may be similar by nature to that on benzodiazepines rather than barbiturates and alcohol.
\end{abstract}

Misuses of methaqualone, a quinazolone derivative hypnotic, for non-medical purposes appear to be quite widespread as suggested by surveys carried out by various workers (1-4). Methaqualone has been reported to cause dependence in man (5-7). Physical dependence develops from the chronic use of methaqualone at doses of above $7.5 \mathrm{~g}$ daily. The doses of $2 \mathrm{~g}$ daily of methaqualone used for one month is sufficient to produce withdrawal seizures (8).

In laboratory animals such as dogs $(9,10)$. rats $(11,12$ ) and mice (13), evidence for physical dependence on methaqualone has been reported. Severe physical dependence on methaqualone, as manifested by spontaneous convulsions after its withdrawal, has not been however documented, suggesting that physical dependence on methaqualone is a mild type. Moreover, Yanagita and Miyasato (14) found that methaqualone produced no physical dependence in rhesus monkeys. but functioned as a reinforcer for monkeys in an intravenous self-administration procedure. However, Suzuki et al. (15) reported that severe physical dependence on methaqualone, which was characterized by spontaneous convulsions during withdrawal. was easily developed by the drug-admixed food (DAF) method in female and male rats.

Dependence-producing drugs are classified into 9 types (16). Methaqualone belongs to the barbiturate type. There are some reports of cross-physical dependence liability among sedative-hypnotics including methaqualone in dogs (9), monkeys (17). rats (18) and mice (19). In barbital- or pentobarbital-dependent dogs, the degree of withdrawal signs after barbiturate withdrawal was lessened by methaqualone $(9,10)$.

The purpose of the present study was to evaluate the characteristics of physical dependence on methaqualone. We therefore investigated the degree of inhibition of 
methaqualone withdrawal signs by crossadministration of several CNS depressants (barbital, pentobarbital, ethanol and diazepam).

\section{Materials and Methods}

Animals: Male Sprague-Dawley rats weighing $150-200 \mathrm{~g}$ at the beginning of the experiment were used. Animals were housed in individual cages under a 12-hr light-dark cycle with food and water continuously available. The room temperature was maintained at $22 \pm 1{ }^{\circ} \mathrm{C}$, and the relative humidity was maintained at $55 \pm 5 \%$. The rats were allowed to adapt to their environment for a period of 1 week.

Development of physical dependence: For preparing the drug-admixed food, methaqualone was mixed with a normal powdered food (CA-1, Japan Clea, Tokyo) in a mortar (20. 21). Each rat was allowed to eat the methaqualone-admixed food and to drink tap water ad libitum. For developing the physical dependence on methaqualone, the rats were chronically treated with methaqualone according to the method of Suzuki et al. (15) The concentration of methaqualone in the food was gradually increased from 1 and 2 to 10 and $12 \mathrm{mg} / \mathrm{g}$ of food for 33 days.

ED50 of test drugs in rotarod performance test: Motor incoordination was evaluated by the rotarod performance test $(9 \mathrm{~cm}$ in diameter, $5.3 \mathrm{rpm}$; Natsume Seisakusho Co., Tokyo) in naive rats. Motor incoordination was assessed by the complete inability of the animal to walk on the rotarod in each of three trials. Median effective doses (ED50) for motor impairment were calculated by the up and down method (22). Rats were examined by the rotarod performance test after administration of pentobarbital (at 15 min after i.p.), barbital (30 $\mathrm{min}$ after i.p.). ethanol (15 $\mathrm{min}$ after i.p.) and diazepam (45 min after p.o.).

Cross-physical dependence on test drugs: Withdrawal was conducted by substituting normal food for methaqualone-admixed food at 14:00 of the last day of the treatment in all rats. Cross-administration of test drugs was started from $9 \mathrm{hr}$ after the methaqualone withdrawal. The dose of ED50 for motor impairment was used for cross-administration as the minimal dose of each drug
Three doses of each test drug and saline or $0.5 \% \mathrm{CMC}$ as the respective control were administered with the same schedule. Pentobarbital $(25.4,33.0$ and $42.9 \mathrm{mg} / \mathrm{kg}$, i.p.) was administered 8 times at 1.5 -hr intervals until $16.5 \mathrm{hr}$ after the withdrawal. Barbital (156, 203 and $264 \mathrm{mg} / \mathrm{kg}$, i.p.) was administered only once at $9 \mathrm{hr}$ after the withdrawal. Ethanol $(2.18,2.83$ and $3.68 \mathrm{~g} / \mathrm{kg}$, i.p.) and diazepam $(65.0,84.5$ and $109.9 \mathrm{mg} / \mathrm{kg}$. p.o.) were administered twice at 9 and $15 \mathrm{hr}$ after the withdrawal.

During and after the cross-administration, body weight and food intake were measured every $3 \mathrm{hr}$ and withdrawal signs were observed. Suppression of body weight loss by the cross-administration was used as an index for the evaluation of cross-physical de pendence liability to test drugs. The area under

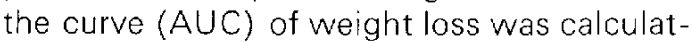
ed by percent change in weight loss between the starting point of cross-administration of the test drugs ( $9 \mathrm{hr}$ after the withdrawal) and $27 \mathrm{hr}$ after the methaqualone withdrawal. Moreover, the following rating score for withdrawal signs was used according to the method of Tagashira et al. (23), with a minor modification. The withdrawal signs were classified into four grades: no abnormality (score 0), mild (score 1), intermediate (score 2) and severe (score 3).

Statistical analysis: Analysis for the incidence of withdrawal signs was performed by the chi-square $(2 \times 2)$ test. All other analyses were carried out using Student's $t$-test.

\section{Results}

Pentobarbital: The cross-administration with three doses $(25.4 .33 .0$ and $42.9 \mathrm{mg} / \mathrm{kg}$ ) of pentobarbital caused a slight inhibition of body weight loss by methaqualone withdrawal. However, body weight did not increase by pentobarbital injections and gradually kept decreasing (Fig. 1). AUCs of weight loss for $25.4,33.0,42.9 \mathrm{mg} / \mathrm{kg}$ of pentobarbital and the control were $69.38 \pm$ 9.83, $\quad 65.02 \pm 21.14, \quad 88.01 \pm 14.40$ and $128.15 \pm 18.04$, respectively (Fig. 2). The AUC of weight loss at the lowest dose of pentobarbital. $25.4 \mathrm{mg} / \mathrm{kg}$. Was significantly smaller than that in the control. Straub's tail reaction was significantly inhibited at 33.0 and 42.9 

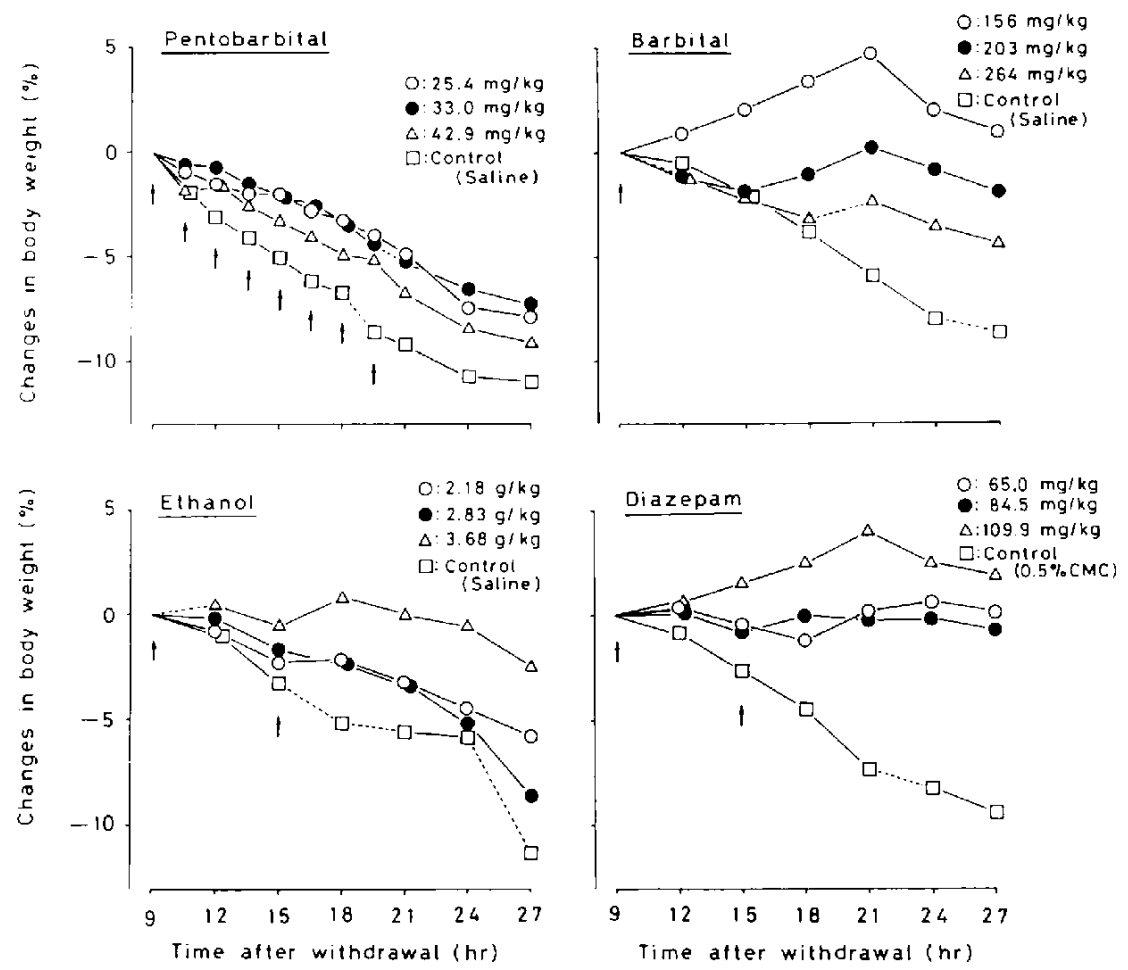

Fig. 1. Time course of changes in body weight after the cross-administrations of several drugs in methaqualone-dependent rats. Each test drug was cross-administered from $9 \mathrm{hr}$ after the methaqualone withdrawal. The arrows indicate the cross-administration of the test drugs and saline or $0.5 \% \mathrm{CMC}$. The dotted line represents that one rat died.

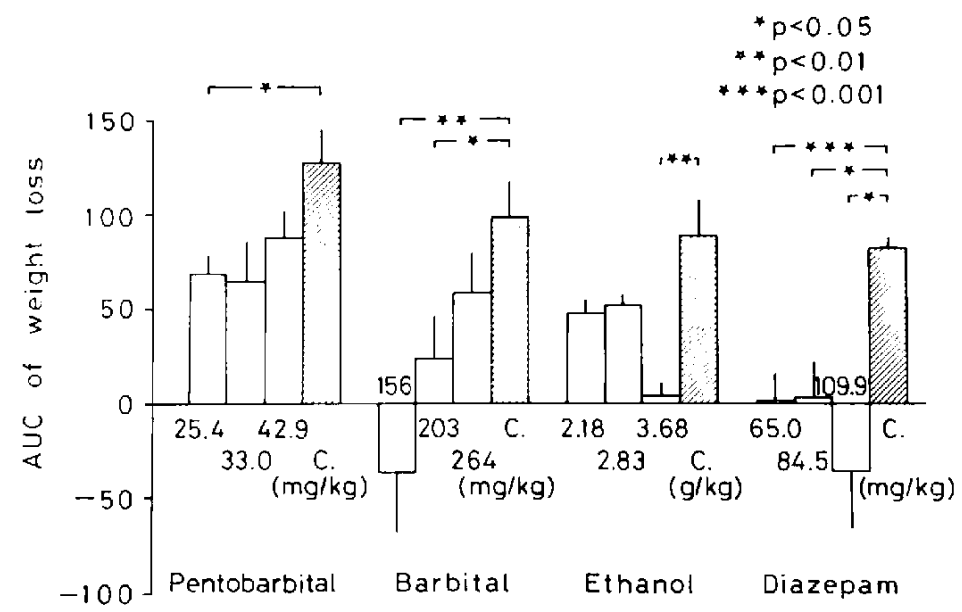

Fig. 2. Effects of several sedative-hypnotics on body weight loss after the methaqualone withdrawal. Cross-physical dependence liability of these drugs was evaluated by AUC. AUC of weight loss was calculated by changes of body weight between the starting point of cross-administration ( 9 hr after the withdrawal) and $27 \mathrm{hr}$ after the withdrawal. The numerals near the columns represent the doses of drugs. C: control. 
$\mathrm{mg} / \mathrm{kg}$ of pentobarbital as compared to the control $(P<0.05$, Table 1). Withdrawal scores for $25.4 .33 .042 .9 \mathrm{mg} / \mathrm{kg}$ of pento-

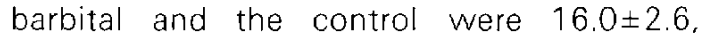
$11.5 \pm 3.2,14.7 \pm 1.9$ and $16.7 \pm 2.4$, respectively. There was no significant difference in the withdrawal scores between any dose of pentobarbital and the control.

Barbital: The cross-administration with barbital inhibited body weight loss by methaqualone withdrawa I(Figs. 1 and 2). The converse dose-related inhibition was observed. AUCs of weight loss for 156, 203.264 mg/ $/ \mathrm{kg}$ of barbital and the control were $-36.76 \pm$ $31.06, \quad 24.17 \pm 23.00, \quad 59.39 \pm 21.08$ and $98.86 \pm 19.44$, respectively. The cross-administration of the low and medium barbital doses significantly inhibited the weight loss by methaqualone withdrawal. In the case of the low dose $(156 \mathrm{mg} / \mathrm{kg})$, body weight after the cross-administration increased. Withdrawal scores for 156, 203, $264 \mathrm{mg} / \mathrm{kg}$ of barbital and the control were $2.3 \pm 1.3$, $2.2 \pm 0.6,0.8 \pm 0.5$ and $15.6 \pm 2.0$, respectively (Table 2). By the cross-administration with all 3 doses of barbital, the withdrawal scores showed a significant inhibition as compared to those in the control. During the cross-administration with 203 and $264 \mathrm{mg} / \mathrm{kg}$, barbital-induced sleep was observed in 3 out of 5 and 4 out of 6 rats tested, respectively.

Ethanol: The cross-administration with the low $(2.18 \mathrm{~g} / \mathrm{kg})$ and medium $(2.83 \mathrm{~g} / \mathrm{kg})$ doses of ethanol failed to inhibit body weight loss by methaqualone withdrawal (Figs. 1 and 2). The high dose $(3.68 \mathrm{~g} / \mathrm{kg})$ of ethanol significantly inhibited body weight loss as compared to the control $(P<0.01)$. AUCs of weight loss for $2.18,2.83,3.68 \mathrm{~g} / \mathrm{kg}$ of ethanol and the control were $47.98 \pm 7.86,51.87 \pm$ $6.04,4.27 \pm 6.67$ and $88.99 \pm 18.72$, respectively. Withdrawal scores for 2.18, 2.83, 3.68 $\mathrm{g} / \mathrm{kg}$ of ethanol and the control were $12.3 \pm$ $2.5,7.3 \pm 2.1,0.6 \pm 0.2$ and $14.8 \pm 2.2$, respectively (Table 3). The withdrawal scores for 2.83 and $3.68 \mathrm{~g} / \mathrm{kg}$ of ethanol were significantly smaller than that in the control. During the cross-administration with 2.83 and 3.68 $\mathrm{g} / \mathrm{kg}$ of ethanol, ethanol-induced sleep was observed in 1 out of 6 and all the rats tested. respectively.

Diazepam: The cross-administration with

Table 1. Behavioral changes during pentobarbital cross-administration in methaqualone-dependent rats

\begin{tabular}{|c|c|c|c|c|}
\hline \multirow{3}{*}{$\begin{array}{c}\text { Withdrawal signs } \\
\text { (score) }\end{array}$} & \multicolumn{3}{|c|}{ Positive animals/Used animals } & \multirow{3}{*}{$\begin{array}{l}\text { Control } \\
\text { (saline) }\end{array}$} \\
\hline & \multicolumn{3}{|c|}{ Pentobarbital ( $\mathrm{mg} / \mathrm{kg}$ ) } & \\
\hline & 25.4 & 33.0 & 42.9 & \\
\hline \multicolumn{5}{|c|}{ Weight loss (percent of $A \cup C$ from control) } \\
\hline $0 \%>(0)$ & $0 / 6$ & $0 / 5$ & $0 / 6$ & - \\
\hline $0-30(1)$ & $0 / 6$ & $1 / 5$ & $0 / 6$ & $\ldots$ \\
\hline $30-60\langle 2\rangle$ & $3 / 6$ & $2 / 5$ & $3 / 6$ & - \\
\hline $60 \%<(3)$ & $3 / 6$ & $2 / 5$ & $3 / 6$ & $6 / 6$ \\
\hline Vocalization (2) & $3 / 6$ & $3 / 6$ & $1 / 6$ & $1 / 6$ \\
\hline Irritability (2) & $2 / 6$ & $2 / 6$ & $2 / 6$ & $0 / 6$ \\
\hline Aggression (2) & $1 / 6$ & $0 / 6$ & $0 / 6$ & $1 / 6$ \\
\hline Muscle rigidity (2) & $6 / 6$ & $6 / 6$ & $6 / 6$ & $6 / 6$ \\
\hline Straub's tail (2) & $1 / 6$ & $0 / 6^{*}$ & $0 / 6^{*}$ & $4 / 6$ \\
\hline Ear-twitching (2) & $5 / 6$ & $3 / 6$ & $5 / 6$ & $5 / 6$ \\
\hline Fascicular-twitch (3) & $5 / 6$ & $3 / 6$ & $5 / 6$ & $5 / 6$ \\
\hline Tremor (3) & $5 / 6$ & $3 / 6$ & $5 / 6$ & $5 / 6$ \\
\hline Convulsion (3) & $5 / 6$ & $3 / 6$ & $5 / 6$ & $5 / 6$ \\
\hline Death (3) & $0 / 6$ & $1 / 6$ & $0 / 6$ & $1 / 6$ \\
\hline Withdrawal scores & $16.0 \pm 2.6$ & $11.5 \pm 3.2$ & $14.7 \pm 1.9$ & $16.7 \pm 2.4$ \\
\hline
\end{tabular}

*P<0.05 vs. control. The chi-square $(2 \times 2)$ test was used in the statistical evaluation for each withdrawal sign. The withdrawal scores were calculated by the sum of the rating score per animal. 
$65.0,84.5$ and $109.9 \mathrm{mg} / \mathrm{kg}$ of diazepam comaqualone withdrawal (Figs. 1 and 2). Body pletely inhibited body weight loss by methweight at 65.0 and $84.5 \mathrm{mg} / \mathrm{kg}$ of diazepam

Table 2. Behavioral changes during barbital cross-administration in methaqualone-dependent rats

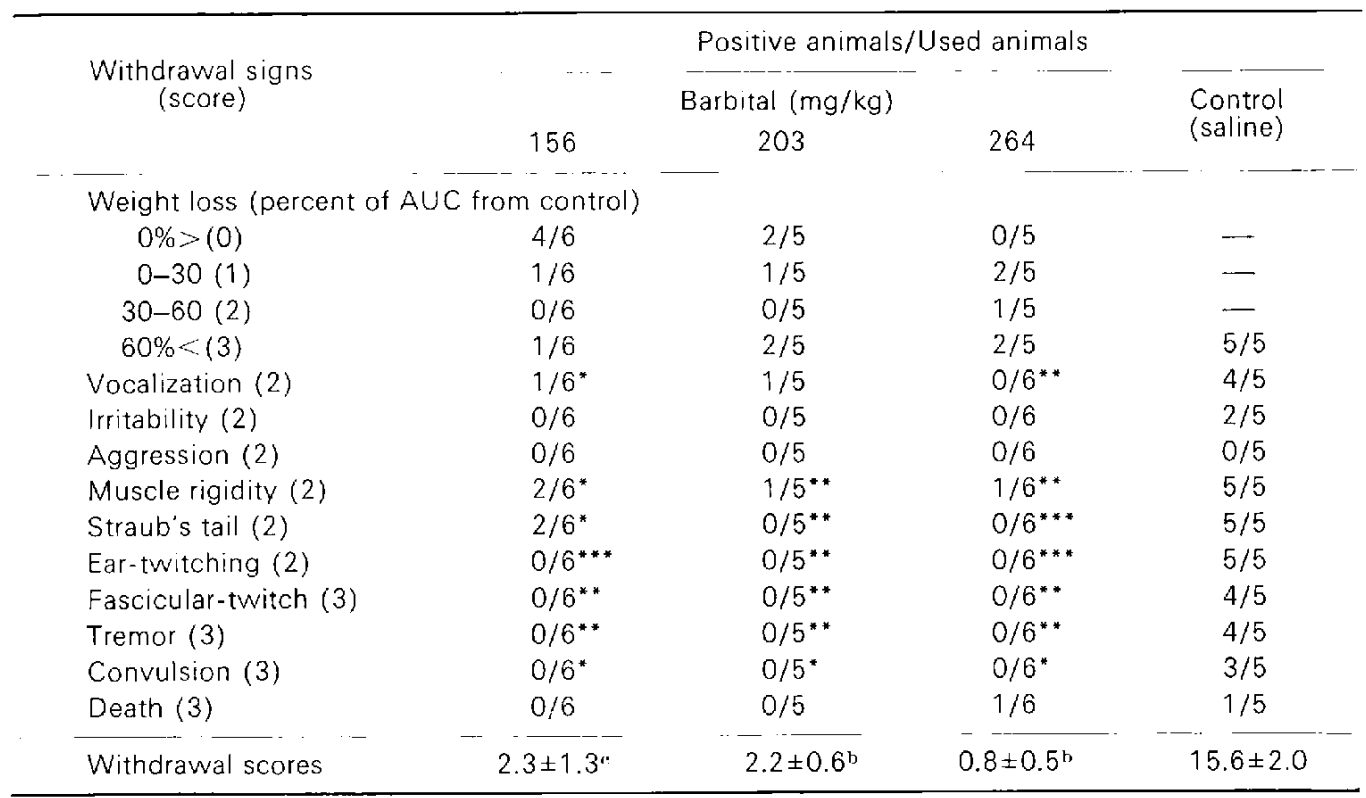

${ }^{*} P<0.05,{ }^{*} P<0.01,{ }^{* *} P<0.001$ vs. control. The chi-square $(2 \times 2)$ test was used in the statistical

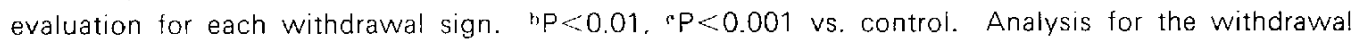
scores was performed by Student's $t$-test. The withdrawal scores were calculated by the sum of the rating score per animal.

Table 3. Behaviaral changes during ethanol cross-administration in methaqualone-dependent rats

\begin{tabular}{|c|c|c|c|c|}
\hline \multirow{3}{*}{$\begin{array}{l}\text { Withdrawal signs } \\
\text { (score) }\end{array}$} & \multicolumn{4}{|c|}{ Positive animals/Used animals } \\
\hline & \multicolumn{3}{|c|}{ Ethanol $(\mathrm{g} / \mathrm{kg})$} & \multirow{2}{*}{$\begin{array}{l}\text { Control } \\
\text { (saline) }\end{array}$} \\
\hline & 2.18 & 2.83 & 3.68 & \\
\hline \multicolumn{5}{|c|}{ Weight loss (percent of AUC from control) } \\
\hline $0 \%>\langle 0\rangle$ & $0 / 6$ & $0 / 6$ & $2 / 5$ & - \\
\hline $0-30(1)$ & $1 / 6$ & $0 / 6$ & $3 / 5$ & - \\
\hline $30-60(2)$ & $3 / 6$ & $5 / 6$ & $0 / 5$ & - \\
\hline $60 \%<(3)$ & $2 / 6$ & $1 / 6$ & $0 / 5$ & $6 / 6$ \\
\hline Vocalization (2) & $3 / 6$ & $2 / 6$ & $0 / 5$ & $3 / 6$ \\
\hline Irritability (2) & $0 / 6$ & $0 / 6$ & $0 / 5$ & $0 / 6$ \\
\hline Aggression (2) & $0 / 6$ & $0 / 6$ & $0 / 5$ & $0 / 6$ \\
\hline Muscle rigidity (2) & $6 / 6$ & $5 / 6$ & $0 / 5^{* * *}$ & $6 / 6$ \\
\hline Straub's tail (2) & $4 / 6$ & $4 / 6$ & $0 / 5^{* * *}$ & $6 / 6$ \\
\hline Ear-twitching (2) & $4 / 6$ & $1 / 6$ & $0 / 5^{*}$ & $4 / 6$ \\
\hline Fascicular-twitch (3) & $4 / 6$ & $1 / 6$ & $0 / 5$ & $3 / 6$ \\
\hline Tremor $(3)$ & $4 / 6$ & $1 / 6$ & $0 / 5$ & $3 / 6$ \\
\hline Convulsion (3) & $1 / 6$ & $1 / 6$ & $0 / 5$ & $2 / 6$ \\
\hline Death (3) & $0 / 6$ & $0 / 6$ & $0 / 5$ & $3 / 6$ \\
\hline Withdrawal scores & $12.3 \pm 2.5$ & $7.3 \pm 2.1^{14}$ & $0.6 \pm 0.2^{\mathrm{h}}$ & $14.8 \pm 2.2$ \\
\hline
\end{tabular}

a $P<0.05, b P<0.01$ vs. control. Other explanations are as in Table 2. 
Table 4. Behavioral changes during diazepam cross-administration in methaqualone-dependent rats

\begin{tabular}{|c|c|c|c|c|}
\hline \multirow{3}{*}{$\begin{array}{c}\text { Withdrawal signs } \\
\text { (score) }\end{array}$} & \multicolumn{4}{|c|}{ Positive animals/Used animals } \\
\hline & \multicolumn{3}{|c|}{ Diazepam (mg/kg) } & \multirow{2}{*}{$\begin{array}{c}\text { Control } \\
(0.5 \% \mathrm{CMC})\end{array}$} \\
\hline & 65.0 & 84.5 & 109.9 & \\
\hline \multicolumn{5}{|c|}{ Weight loss (percent of AUC from control) } \\
\hline $0 \%>(0)$ & $3 / 6$ & $2 / 6$ & $4 / 6$ & - \\
\hline $0-30(1)$ & $1 / 6$ & $2 / 6$ & $0 / 6$ & - \\
\hline $30-60(2)$ & $1 / 6$ & $2 / 6$ & $1 / 6$ & - \\
\hline $60 \%<(3)$ & $1 / 6$ & $0 / 6$ & $1 / 6$ & $6 / 6$ \\
\hline Vocalization (2) & $5 / 6$ & $5 / 6$ & $4 / 6$ & $3 / 6$ \\
\hline Irritability (2) & $0 / 6$ & $1 / 6$ & $0 / 6$ & $2 / 6$ \\
\hline Aggression (2) & $0 / 6$ & $0 / 6$ & $0 / 6$ & $0 / 6$ \\
\hline Muscle rigidity (2) & $5 / 6$ & $4 / 6$ & $3 / 6^{*}$ & $6 / 6$ \\
\hline Straub's tail (2) & $2 / 6^{*}$ & $2 / 6^{*}$ & $3 / 6^{*}$ & $6 / 6$ \\
\hline Ear-twitching (2) & $1 / 6^{*}$ & $1 / 6^{+}$ & $2 / 6$ & $5 / 6$ \\
\hline Fascicular-twitch (3) & $1 / 6$ & $1 / 6$ & $2 / 6$ & $4 / 6$ \\
\hline Tremor (3) & $1 / 6$ & $1 / 6$ & $2 / 6$ & $4 / 6$ \\
\hline Convulsion (3) & $1 / 6$ & $1 / 6$ & $2 / 6$ & $4 / 6$ \\
\hline Death (3) & $0 / 6$ & $0 / 6$ & $0 / 6$ & $1 / 6$ \\
\hline Withdrawal scores & $7.0 \pm 2.1$ & $6.8 \pm 2.3^{\sharp 1}$ & $7.8 \pm 2.4^{4}$ & $16.8 \pm 2.2$ \\
\hline
\end{tabular}

Explanations are as in Table 3

showed almost no decrease from the start of cross-administration. Body weight at 109.9 $\mathrm{mg} / \mathrm{kg}$ increased rather significantly by diazepam cross-administration. AUCs for $65.0,84.5,109.9 \mathrm{mg} / \mathrm{kg}$ and the control were $1.79 \pm 14.76,3.34 \pm 19.51,-35.82 \pm 30.37$ and $82.39 \pm 6.08$, respectively. Withdrawal scores for $65.0,84.5,109.9 \mathrm{mg} / \mathrm{kg}$ and the control were $7.0 \pm 2.1,6.8 \pm 2.3,7.8 \pm 2.4$ and $16.8 \pm$ 2.2 , respectively (Table 4 ). There were significant differences in the withdrawal scores between all the 3 doses of diazepam and the control.

\section{Discussion}

The cross-physical dependence test has been widely used to evaluate the physical dependence liability of sedative-hypnotics because it can be done quickly and economically $(9,17-19)$. In the present study, the cross-physical dependence test was used to investigate the characteristics of physical dependence on methaqualone. We made methaqualone-dependent rats by the DAF method and then examined the degree of suppression of the methaqualone withdrawal signs by cross-administration of test drugs. Barbital as a long-acting barbiturate, pento- barbital as a short-acting barbiturate, ethanol as alcohol and diazepam as a benzodiazepine were evaluated for the liability of cross-physical dependence. According to the classification of dependence-producing drugs by WHO. barbital, pentobarbital and diazepam belong to the barbiturate type (16). However, ethanol belongs to a different type, the alcohol type. which nevertheless possesses cross-physical dependence liability to the barbiturate type (17).

The cross-administration of test drugs was performed from $9 \mathrm{hr}$ after the termination of methaqualone treatment, because several signs of methaqualone withdrawal started to be observed from approximately $9 \mathrm{hr}$ after the withdrawal.

The ED50 for motor impairment was used for cross-administration as the minimal dose of each drug because there is high correlation between motor impairment by sedativehypnotics and severity of withdrawal signs after the termination of drug treatment (24).

The present study showed that all the four test drugs (barbital, pentobarbital, ethanol and diazepam) produced cross-physical dependence to methaqualone. AUCs of weight loss by methaqualone withdrawal were 
significantly inhibited by cross-administration with all the test drugs, as compared to the control (Figs. 1 and 2). Withdrawal scores for barbital at the doses of 156 and $203 \mathrm{mg} / \mathrm{kg}$ and ethanol at the doses of 2.83 and $3.68 \mathrm{~g} /$ $\mathrm{kg}$ were significantly smaller than that in the control. Barbital at the dose of $156 \mathrm{mg} / \mathrm{kg}$ (cross-administration of minimal dose) caused strong suppression of the methaqualone withdrawal signs. Tagashira et al. (25) reported that the cross-administration with barbital inhibited almost all mild to severe withdrawal signs of phenobarbital. They used $40 \mathrm{mg} / \mathrm{kg} \times 4$ and $80 \mathrm{mg} / \mathrm{kg} \times 5$ (p.o.) at $4-6 \mathrm{hr}$ intervals as doses of cross-administration of barbital. These doses were comparable low doses as compared with this study. The suppression of methaqualone withdrawal signs may result from the sleep induced by the cross-administration of high and medium doses of barbital or ethanol. On the other hand, diazepam among the four test drugs indicated the clearest suppression of methaqualone withdrawal signs. These results demonstrate that high doses of diazepam are required for the development and/or maintenance of physical dependence, as compared to the usual doses used in general pharmacological studies. The present study suggests that physical dependence on methaqualone may be more similar to that on benzodiazepines than dependences on barbiturates and ethanol.

Tagashira et al. (25) cross-administered barbital, pentobarbital, ethanol, diazepam, nitrazepam, methaqualone, etc. to evaluate cross-physical dependence liability in phenobarbital-dependent rats. From the mode of suppression and severity of relapsed withdrawal signs, these drugs were classified into 3 types. Barbital belonged to type-l: drugs suppressing withdrawal signs of phenobarbital almost completely with the following relapse of severe withdrawal signs of phenobarbital. Ethanol, pentobarbital, diazepam and methaqualone belonged to type-II-a: drugs suppressing withdrawal signs of phenobarbital partially with the following relapse of moderate withdrawal signs of phenobarbital. Ifenprodil belonged to typeII-b: drugs suppressing withdrawal signs of phenobarbital partially with the following relapse of only mild or practically no signs. Diphenylhydantoin, reserpine, clonidine and chlorpromazine belonged to type-IIl: drugs practically failing to suppress or rather aggravate withdrawal signs of phenobarbital. There are no data about type-lll drugs in the present study, but the report of Tagashira et al. (25) showed that the type-lli drugs did not suppress the withdrawal signs of phenobarbital. Type-lll drugs such as reserpine, clonidine and chlorpromazine may have no cross-physical dependence liability to methaqualone. They therefore showed that barbital possessed the best cross-physical dependence liability to phenobarbital. In the present study, our results suggest that diazepam among the drugs tested possesses the best cross-physical dependence liability to methaqualone.

Methaqualone exhibited a negligible effect on $\left({ }^{3} \mathrm{H}\right) \mathrm{GABA}$ binding in vitro and inhibited $\left({ }^{3} \mathrm{H}\right)$ diazepam binding in vitro $(26)$. $\left({ }^{35} \mathrm{~S}\right) \mathrm{t}$ butylbicyclophosphorothionate binding in vitro was inhibited by methaqualone, and this inhibition was reversed by the bicucullinelike GABA antagonist R5135 (27). The effects of methaqualone might be expected to be mediated via GABA/benzodiazepine/ barbiturate receptor complexes.

\section{References}

1 Gonzáles, E.R.: Methaqualone abuse implicated in injuries, deaths nationwide. JAMA 246, 813819 (1981)

2 Tennant, F.S.: Complication of methaqualonediphenhydramine (Mandrax ${ }^{\circledR}$ ) abuse. $\mathrm{Br}$. J. Addict. 68, 327-330 (1973)

3 Pascarelli, E.F.: Methaqualone abuse, the quiet epidemic. JAMA 224, 1512-1514 (1973)

4 Rock, N.L.: Methaquaione abuse in Europe. JAMA 230, 1389 (1974)

5 Madden, J.S.: Dependency on methaqualone hydrochloride (Melsedin). Br. Med. J. No. 5488. 676 (1966)

6 Ewart, R.B.L. and Priest, R.G.: Methaqualone addiction and delirium tremens. Br. Med. J. 3, 92-93 (1967)

7 Kato, M., Takahashi, N., Miyagawa, K., Tauchi, K., Fuiita, E., Suzuki, T. and Imada, Y.: Clinical and statistica! study on drug dependence, in particular induced by tranquilizing and hypnotic drugs. Clin. Psychiatry 8, 119-128 (1966)

8 Blum, K.: CNS depressants: Sedative-hypnotics 
(barbiturates and nonbarbiturates). In Handbook of Abusable Drugs. p. 165-210, Gardner Press. New York and London (1984)

9 Deneau, G.A. and Weiss, S.: A substitution technique for determining barbiturate-like physiological dependence capacity in the dog. Pharmakopsychiatr. Neuro-Psychopharmakol. 1, 270-275 (1968)

10 Jones, B.E., Prada, J.A. and Martin, W.R.: A method for bioassay of physical dependence or sedative drugs in dog. Psychopharmacology (Berlin) 47, 7-15 (1976)

11 Kohli, R.P., Singh, N. and Kulshrestha, V.K.: An experimental investigation of dependence liability of methaqualone in rats. Psychopharmacologia (Berlin) 35, 327-334 (1974)

12 Singh, N., Nath, R., Kulshrestha, V.K. and Kohli, R.P.: An experimental evaluation of dependence liability of methaqualone diphenhydramine (combination) and methaqualone in rats. Psychopharmacology (Berlin) 67, 203-207 (1980)

13 Alpern, H.P., Greer, C.A., Stripling, J.S., Collins, A.C. and Olson, R.K.: Methaqualone: Tolerance and physical dependence in mice. Psychopharmacologia (Berlin) 44 303-305 (1975)

14 Yanagita, T. and Miyasato, K: Dependence potential of methaqualone tested in rhesus monkeys. Preclin. Rep. Cent. Inst. Exp. Anim. 2, 63-68 (1976)

15 Suzuki, T, Koike, Y. and Misawa, M.: Sex differences in physical dependence on methaqualone in the rat. Pharmacol. Biochem. Behav. 30, (1988) (in press)

16 Kramer, J.F. and Cameron, D.C.: Basic concepts and the use of terms. In A Manual on Drug Dependence, p. 13-17. World Health Organization. Geneva (1975)

17 Yanagita, T. and Takahashi. S.: Dependence liability of several sedative-hypnotic agents evaluated in monkeys. J. Pharmacol. Exp. Ther. 185, 307-316 (1973)

18 Norton, R.R.E.: The effects of drugs on barbiturate withdrawal convulsions in the rat. J. Pharm. Pharmacol. 22, 763-766 (1970)
19 Kaneto, H., Koida, M., Tsuchie, F. and Miyagawa, $H$ : A screening procedure for barbital type physical dependence liability of psychotropic drugs. Folia Pharmacol. Japon. 69, 729-738 (1973) (Abs. in English)

20 Yanaura, S., Suzuki, T. and Tagashira, E.: Study of drug dependence in rats-Substitution test arid time course of body weight. Folia Pharmacol. Japon. 70, 649-658 (1974) (Abs. in English)

21 Yanaura, S., Tagashira, E. and Suzuki, T.: Physical dependence on morphine, phenobarbital and diazepam in rats by drug-admixed food ingestion. Japan. J. Pharmacol. 25, 453-463 (1975)

22 Brownlee, K.A., Hodges, J.L., Jr, and Rosenblatt, $M$.: The up- $\&$-down method with small samples. J. Am. Stat. Assoc. 48, 262-277 (1953)

23 Tagashira, E., kumi, T. and Yanaura, S.: Experimental barbiturate dependence. I. Barbiturate dependence development in rats by drugadmixed food (DAF) method. Psychopharmacology (Berlin) 57, 137-144 (1978)

24 Suzuki, T., Koike, Y., Yanaura, S., George, F.R. and Meisch, R.A.: Genetic differences in the development of physical dependence on pentobarbital in four inbred strains of rats. Japan. J. Pharmacol. 45, 479-486 (1987)

25 Tagashira, E., Urano, T., Hiramori, T. and Yanaura, S.: Cross-physical dependence liability of psychotropic drugs in rats dependent on barbiturates. Japan. J. Pharmacol. 33, 659669 (1983)

26 Koe, B.K., Minor, K.W. Kondratas, E., Lebel, L.A. and Koch, S.W.: Enhancement of benzodiazepine binding by methaqualone and related quinazolinones. Drug Dev. Res. 7, 255-268 (1986)

27 Squires, R.F., Casida, J.E., Richardson, M. and Saederup, E.: ( ${ }^{35}$ S)t-Butylcyclophosphorothionate binds with high affinity to brain specific sites coupled to $\gamma$-aminobutyric acid- $A$ and ion recognition sites. Mol. Pharmacol. 23, 326-336 (1983) 